\title{
Rancang Bangun Pembangkit Listrik Hybrid Angin Dan Surya di Pulau Bengkalis
}

\author{
Johny Custer ${ }^{1}$, Jefri Lianda ${ }^{2}$ \\ Program Studi Teknik Listrik, Jurusan Teknik Elektro \\ Politeknik Negeri Bengkalis \\ Jalan Bathin Alam, Sungai Alam, Bengkalis \\ 1johnycaster@polbeng.ac.id, ${ }^{2}$ jefri@polbeng.ac.id
}

\begin{abstract}
Abstrak- Pada penelitian ini dilakukan optimasi penggunaan tenaga angin sebagai sumber energi listrik Pulau Bengkalis. Saat ini karena keterbatasan dari Pemda Bengkalis, masih banyak daerah pesisir yang belum dialiri listrik secara optimal. Harapan kedepan penggunaan energi hybrid antara surya dan energi angin merupakan suatu terobosan baru dalam bidang ilmu pengetahuan. Makalah ini menjelaskan rancang bangun pembangkit listrik hybrid angin dan surya. Rata-rata kecepatan angin di Bengkalis adalah $2,79 \mathrm{~m} / \mathrm{dt}$ sehingga turbin angin yang digunakan adalah jenis low wind speed (lws) wind turbine dengan daya 300 watt. Pada penelitian Fokus penelitian ini adalah bagaimana menguji unjuk kerja turbin angin Savonius 2 tingkat. Penelitian ini menghasilkan kincir angin dengan daya 59 watt. Tegangan rata-rata yang dihasilkan berupa tegangan AC 3 fasa sebesar 6,57 volt AC sampai dengan 18,61 volt AC. Salah satu metode untuk memaksimalkan daya keluaran dari panel surya dengan mengatur posisi panel surya selalu berhadapan dengan posisi matahari. Panel surya digerakkan oleh dua motor. Motor sumbu $X$ untuk pergerakan arah timur ke arah barat berdasarkan perubahan waktu dalam jam dan motor sumbu $Y$ untuk pergerakan arah selatan ke arah utara berdasarkan perubahan waktu berdasarkan bulan. Hasil penelitian ini mampu mengontrol panel surya untuk mendapatkan hasil daya maksimum sebesar 491 watt. Nilai tegangan yang dihasilkan oleh panel surya dapat ditampilkan melalui LCD melalui sensor tegangan.
\end{abstract}

Kata Kunci- Bengkalis, Hybrid, lws, Surya, LCD.

\section{PENDAHULUAN}

Salah satu sumber energi terbarukan yang sangat berpotensi di Indonesia, khususnya di pulau Bengkalis dengan wilayah beriklim tropis dan hembusan angin yang relatif kuat adalah pemanfaatan angin dan sinar matahari sebagai pembangkit listrik terbarukan. Energi angin dan matahari merupakan salah satu potensi energi terbarukan yang dapat memberikan kontribusi terhadap kebutuhan energi listrik, khususnya diwilayah pesisir dan terpencil.
Penggunaan energi surya dan energi angin merupakan suatu terobosan baru dalam bidang ilmu pengetahuan dan teknologi yang hingga kini masih terus dikembangkan untuk kebutuhan manusia. Selain memiliki ketersediaan sumber energi yang melimpah, penggunaan teknologi sel surya ini juga ramah terhadap lingkungan. Akan tetapi karena kondisi lingkungan yang tidak stabil atau konsisten, maka alangkah baiknya jika langsung memanfaatkan kedua jenis energi ini secara bersamaan. Penggunaan dua energi secara bersamaan atau lebih dikenal dengan teknologi hybrid.

\section{LANDASAN TEORI}

Energi angin merupakan bentuk energi terbarukan yang paling banyak tersedia di antara semua sumber energi. Energi angin dapat diambil oleh turbin angin dan dapat dikonversi menjadi energi listrik dengan menggunakan alat pembangkit listrik yang tepat. Proses ini benar-benar ramah lingkungan dan biaya yang terkait dengan fabrikasi yang sangat sedikit[1]. Indonesia memiliki potensi energi angin laut secara signifikan melimpah, diperkirakan bahwa Indonesia memiliki sekitar 9,29 GW potensi energi angin[2].Tenaga surya sebagai sumber clean energi menjadi banyak diminati untuk dilakukan penelitian lebih lanjut [3]. Panel surya yang terpasang saat ini masih bersifat permanen, sehingga penerimaan intensitas sinar matahari belum maksimal [4]

Berdasarkan pengaruh rotasi bumi dan revolusi bumi pada system tata surya akan terdapat fenomena yang berbeda. Pada saat bumi berevolusi, bumi juga melakukan gerak rotasi yaitu berputar pada porosnya. Salah satu gejala yang ditimbulkan saat bumi berotasi adalah peristiwa siang dan malam (perbedaan permukaan bumi yang menghadap ke matahari). Revolusi bumi adalah peredaran bumi mengelilingi matahari, selama revolusi bumi condong atau miring dengan arah yang sama terhadap bidang ekliptika, terbentuk sudut $23,5^{\circ}$. Revolusi bumi salah satunya dapat mengakibatkan gerak semu 
tahunan matahari, pengamatan yang dapat dilakukan adalah melihat kedudukan matahari yang seakan-akan bergerak dari katulistiwa ke $23,5^{0}$ LU kembali ke katulistiwa, terus ke $23,5^{\circ}$ LS, dan kembali lagi ke katulistiwa. Oergesaran kedudukan matahari yang demikian itu berlangsung setiap 1 tahun. Dengan demikian untuk mendapatkan intensitas sinar matahari secara maksimal dapat dilakukan dengan penjejakan dua lintas edar, yaitu dari arah timur ke barat dan arah utara ke selatan [4].

Mairizwan dan hendro [5] pada penelitiannya telah berhasil meningkatkan daya keluaran yang lebih besar dibandingkan sel surya statis sebesar 14,03\% menggunakan sistem tracker. Yudhy, dkk [6] mampu menghasilkan energi panel surya sebesar 70,45 Wh menggunakan sistem penggerak otomatis menggunakan motor servo pada sudut $30^{\circ}, 50^{\circ}, 70^{\circ}, 90^{\circ}, 110^{\circ}$, $130^{\circ}$, dan $150^{\circ}$. Noer dan Osea [5] menunjukkan bahwa sistem pelacak energi surya otomatis ini mampu menyimpan energi listrik rata-rata sebesar 67,18 watt-jam atau 99,97\% dari energi yang dihasilkan panel surya selama pengujian. Daya listrik yang diperoleh oleh sistem ini lebih besar dibandingkan daya listrik yang diperoleh bila posisi panel surya yang tetap pada $60^{\circ}$.

Penelitian ini mengoptimasikan penggunaan tenaga angin sebagai sumber energi listrik Pulau Bengkalis dengan boost converter dan mengontrol pergerakan panel surya secara dua dimensi berbasis arduino yang dilengkapi dengan tampilan LCD untuk memperlihatkan nilai dari tegangan keluaran panel surya. Pergerakan panel surya dilakukan secara otomatis, motor sumbu $\mathrm{X}$ untuk pergerakan arah timur ke barat dan motor sumbu Y untuk pergerakan arah selatan ke utara.

Daya adalah energi per satuan waktu. Daya angin berbanding lurus dengan kerapatan udara, dan kubik kecepatan angin, seperti diungkapkan dengan persamaan berikut:

$$
P=\frac{1}{2} \rho V^{3}\left[\text { watt } / \mathrm{m}^{2}\right]
$$

Dimana:

$$
\begin{aligned}
& \mathrm{P}: \text { Daya ouput (watt), } \\
& \rho: \text { kerapatan udara }\left(\mathrm{kg} / \mathrm{m}^{3}\right), \\
& \mathrm{V}: \text { kecepatan angin }(\mathrm{m} / \mathrm{s})
\end{aligned}
$$

Kelajuan perputar baling- baling secara konvesional dinyatakan dengan bilangan tak berdimensi yang dikenal dengan nama tip speed ratio $(\boldsymbol{\lambda})$. lamda merupakan perbandingan kelajuan baling- baling pada radius $\mathrm{R}$ ketika berputar pada $\omega \mathrm{rad} /$ detik terhadap kecepatan angin $v$, yakni [6]:

$$
\lambda=\frac{\omega R}{V}
$$

dengan: $\omega=2 \pi n$ dan $\mathrm{n}=$ putaran baling-baling (rpm)

$$
\begin{aligned}
& \mathrm{R}=\text { Jari-jari rotor }(\mathrm{m}) \\
& \mathscr{V}=\operatorname{Kecepatan} A \operatorname{nin}(\mathrm{m} / \mathrm{s})
\end{aligned}
$$

Untuk menghitung daya listrik

$$
\mathrm{P}=\mathrm{V} . \mathrm{I}
$$

dengan: $\quad P=$ Daya listrik $(\mathrm{W})$

$\mathrm{V}=$ Tegangan listrik $(\mathrm{V})$

$\mathrm{I}=\operatorname{Arus~listrik}(\mathrm{A})$
Menentukan kecepatan poros dan torsi,

$$
\begin{gathered}
\text { Kecepatan poros }=\frac{60 \lambda V}{\pi D} \\
\text { Torsi }=\frac{V^{2} r^{3}}{\lambda}
\end{gathered}
$$

dengan $: \lambda=$ Tip speed ratio

$$
\begin{aligned}
\mathscr{V} & =\text { Kecepatan angin dalam } \mathrm{m} / \mathrm{s} \\
\pi & =3.14 \\
\mathrm{D} & =\text { Diameter blade }(\mathrm{m}) \\
\mathrm{r} & =\text { Jari-jari blade }(\mathrm{m})
\end{aligned}
$$

$$
\text { Luas blade }=1 / 2\left(\mathrm{~s}_{1}+\mathrm{s}_{2}\right) \times \mathrm{t}
$$

dengan : $\mathrm{s}_{1}$ dan $\mathrm{s}_{2} \quad=$ sisi sejajar pada trapesium

$$
\mathrm{t}=\text { tinggi trapezium }
$$

$$
\mathrm{t}=\frac{\text { luas }}{\frac{1}{2}\left(S_{1}+S_{2}\right)}
$$

Diameter suatu rotor kincir angin dapat pula diperoleh melalui sebuah perhitungan. Persamaan untuk menghitung diameter suatu rotor kincir angin.

dengan:

$$
\mathrm{D}=\left(\mathrm{P} \times(47 \lambda \times n)^{3}\right)^{0,2}
$$

$\mathrm{D}=$ Diameter blade $(\mathrm{m})$

$\mathrm{P}=$ Daya listrik yang dibutuhkan (Watt)

$\lambda=$ Tip speed ratio

$\mathrm{n}=$ Jumlah putaran yang memungkinkan dari Generator (rpm)

Turbin angin sumbu vertikal (VAWT) memiliki poros/sumbu rotor utama yang disusun tegak lurus. Kelebihan utama susunan ini adalah turbin tidak harus diarahkan ke angin agar menjadi efektif. Kelebihan ini sangat berguna di tempattempat yang arah anginnya sangat bervariasi. VAWT mampu mendayagunakan angin dari berbagai arah. Dengan sumbu yang vertikal, generator serta gearbox bisa ditempatkan di dekat tanah, jadi menara tidak perlu menyokongnya dan lebih mudah diakses untuk keperluan perawatan. Tapi ini menyebabkan sejumlah desain menghasilkan tenaga putaran yang berdenyut. Drag (gaya yang menahan pergerakan sebuah benda padat melalui fluida (zat cair atau gas) bisa saja tercipta saat kincir berputar. Karena sulit dipasang di atas menara, turbin sumbu tegak sering dipasang lebih dekat ke dasar tempat ia diletakkan, seperti tanah atau puncak atap sebuah bangunan. Kecepatan angin lebih pelan pada ketinggian yang rendah, sehingga yang tersedia adalah energi angin yang sedikit. Aliran udara di dekat tanah dan obyek yang lain mampu menciptakan aliran yang bergolak, yang bisa menyebabkan berbagai permasalahan yang berkaitan dengan getaran, diantaranya kebisingan dan bearing wear yang akan meningkatkan biaya pemeliharaan atau mempersingkat umur turbin angin.

Hibrid sistem atau Pembangkit Listrik Tenaga Hibrid yang disingkat PLTH adalah gabungan atau integrasi antara dua atau 
lebih pembangkit listrik dengan sumber energi yang berbeda. Energi listrik hibrid sangat cocok untuk dipasang di beberapa wilayah pesisir kawasan Indonesia. Pembangkit listrik ini merupakan sumber energi terbarukan yang paling relevan untuk dikembangkan di Indonesia dikarenakan potensi energi surya di Indonesia sangat tinggi, dengan intensitas radiasi ratarata $4-5 \mathrm{kWh} / \mathrm{m} 2$. Keuntungan dari teknologi hibrid berbabasis energi surya dan energi angin ini sangat terasa penting saat ketika dalam keadaan yang tidak menentu, misalkan pada saat hujan berangin. Meskipun sel surya tidak dapat berfungsi tetapi kincir angin masih dapat berfungsi untuk menghasilkan energi listrik, begitu pula sebaliknya. Namun, jika hanya berbasis satu energi akan mengalami gangguan ketika cuaca tidak sesuai dengan teknologi energi yang digunakan.

\section{III.METODOLOGI}

Penelitian ini terlaksana dua tahap. Tahap pertama pembuatan pembangkit kincir angin menggunakan generator magnet permanen dan tahap kedua membahas sistem kontrol panel surya berbasis arduino. Pada tahap pertama peneliti merancang kincir angin dan merealisasikan bentuk perancangan yang telah dibuat sebelumnya ke dalam bentuk nyata atau bentuk sebenarnya. Realisasi alat dilakukan setelah pengujian di laboratorium selesai dilakukan. Flowchat yang digunakan dalam penelitian dapat dilihat pada gambar 1 .

Untuk mendapatkan Desain kincir angin yang sesuai untuk keadaan geografi kepulauan Indonesia diperlukan data-data angin (kecepatan rata-rata, pola, dan peta), pola konsumsi listrik pelabuhan nelayan tradisional, dan potensi keberlanjutan transfer teknologi kincir angin (pemeliharaan dan penggantian komponen). Variabel yang paling menentukan sebuah desian kincir angin adalah ketersediaan angin yang cukup untuk menghasilkan energi listrik melalui generator. Setelah mengetahui pola konsumsi energi listrik pelabuhan nelayan tradisional kemudian dapat menghitung kapasitas sebuah kincir angin yang diperlukan secara stand-alone.

Spesisfikasi alat konversi kincir angin yang digunakan memiliki spesifikasi seperti terdapat dalam pembahasan. Parameter yang diukur adalah kecepatan angin, tegangan keluaran generator listrik permanen, dan daya listrik. Selanjutnya kincir angin akan mengakomodasi kebutuhan yang telah diketahui dan berusaha untuk memberikan perhitungan biaya seminim mungkin dengan utilitas sebesar mungkin.

Metodologi yang digunakan dalam penelitian pada tahap kedua dapat dilihat pada Gambar 2. Secara umum blok diagram sistem kontrol panel surya dua dimensi berbasis arduino diperlihatkan pada Gambar 2. Arduino menerima masukan dari sensor tegangan, membaca waktu RTC, menggerakan motor X dan motor Y serta menampilkan nilai tegangan di LCD.

Rangkaian kontrol sistem kontrol panel surya dua dimensi berbasis arduino yang digunakan pada penelitian ini diperlihatkan pada Gambar 3.

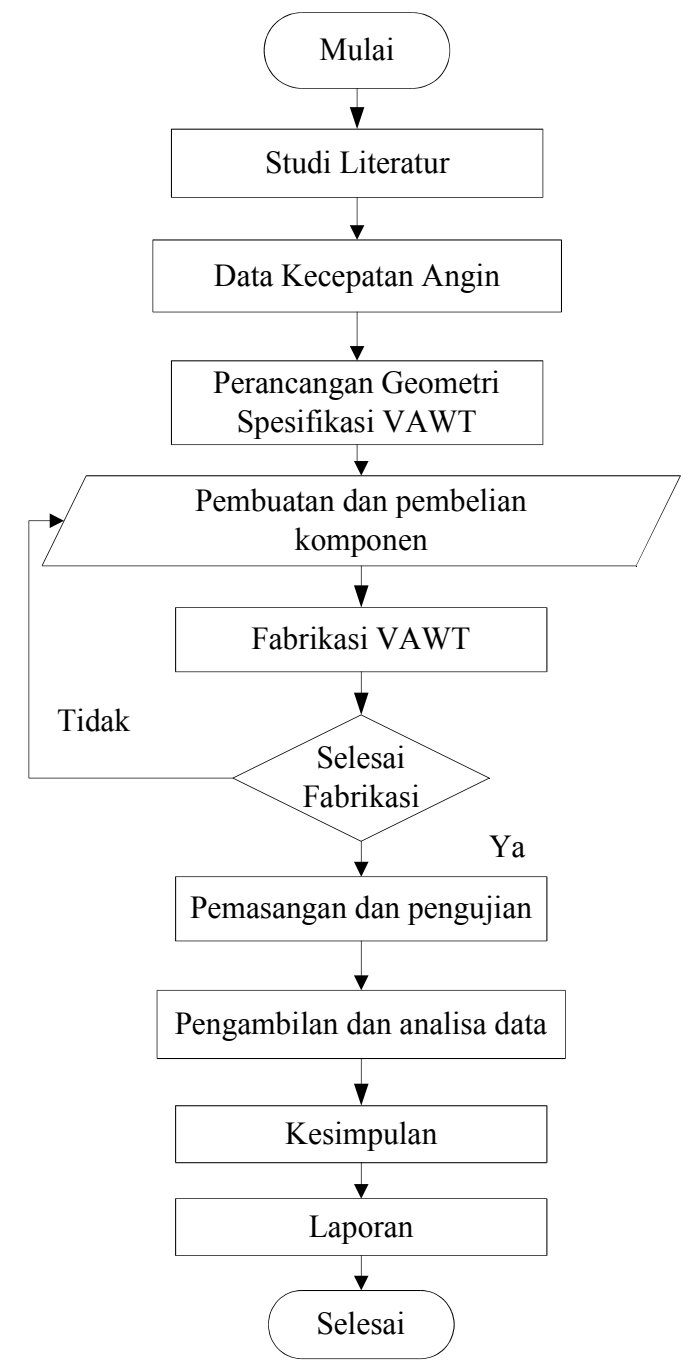

Gambar 1. Bagan alir kegiatan penelitian tahap pertama

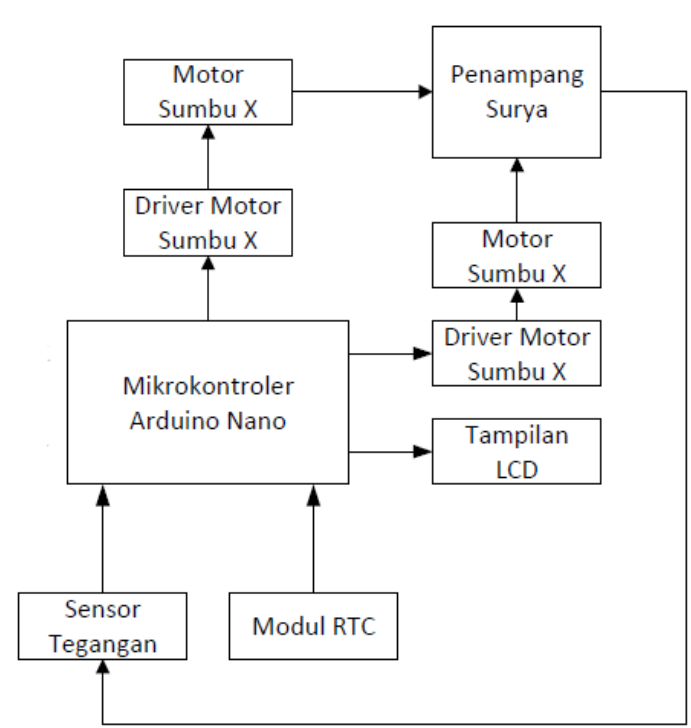

Gambar 2. Blok diagram sistem kontrol panel surya dua dimensi berbasis arduino 


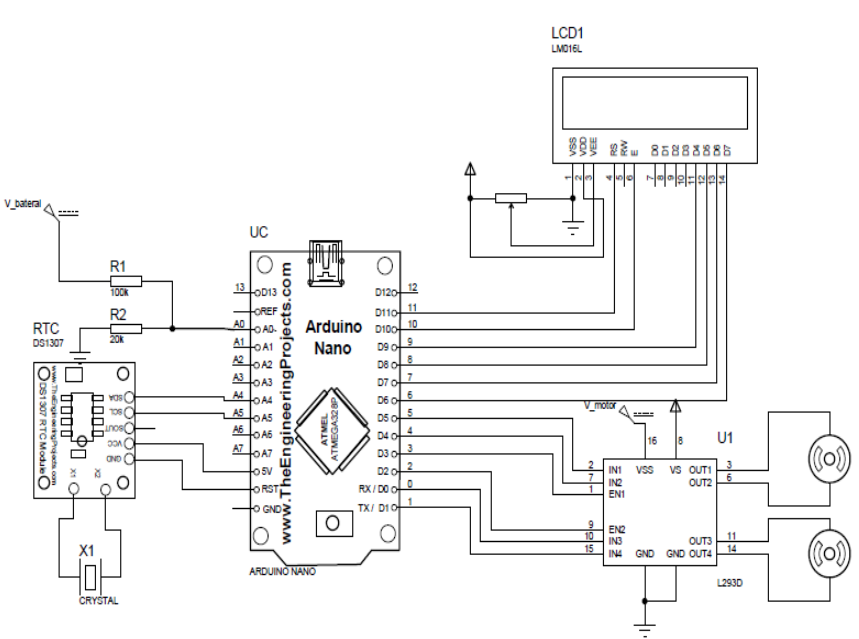

Gambar 3. Rangkaian kontrol panel surya dua dimensi berbasis arduino

\section{IV.HASIL DAN PEMBAHASAN}

Bentuk fisik dari rancang bangun Vertical Wind Axis Turbin (VWAT) dua tingkat diperlihatkan pada Gambar 4. Sudu-sudu kincir angin dengan ukuran $45 \mathrm{~cm}$ x $50 \mathrm{~cm}$.

Pengujian dilaksanakan di kampus Jurusan Teknik Perkapalan Politeknik Negeri Bengkalis. Pengambilan data dimulai pada jam $09^{00}$ WIB. Kecepatan angin rata-rata pada saat pengujian sekitar $2,75 \mathrm{~m} / \mathrm{s}$ sampai dengan $6,18 \mathrm{~m} / \mathrm{s}$ Tegangan yang hasilkan oleh generator magnet permanen sekitar 6,57 volt AC sampai dengan 18,61 volt AC. Data yang diperoleh dari pengukuran berupa tegangan keluaran dari generator magnet permanen dan kecepatan angin pda waktu tertentu ditunjukkan pada Table 1.

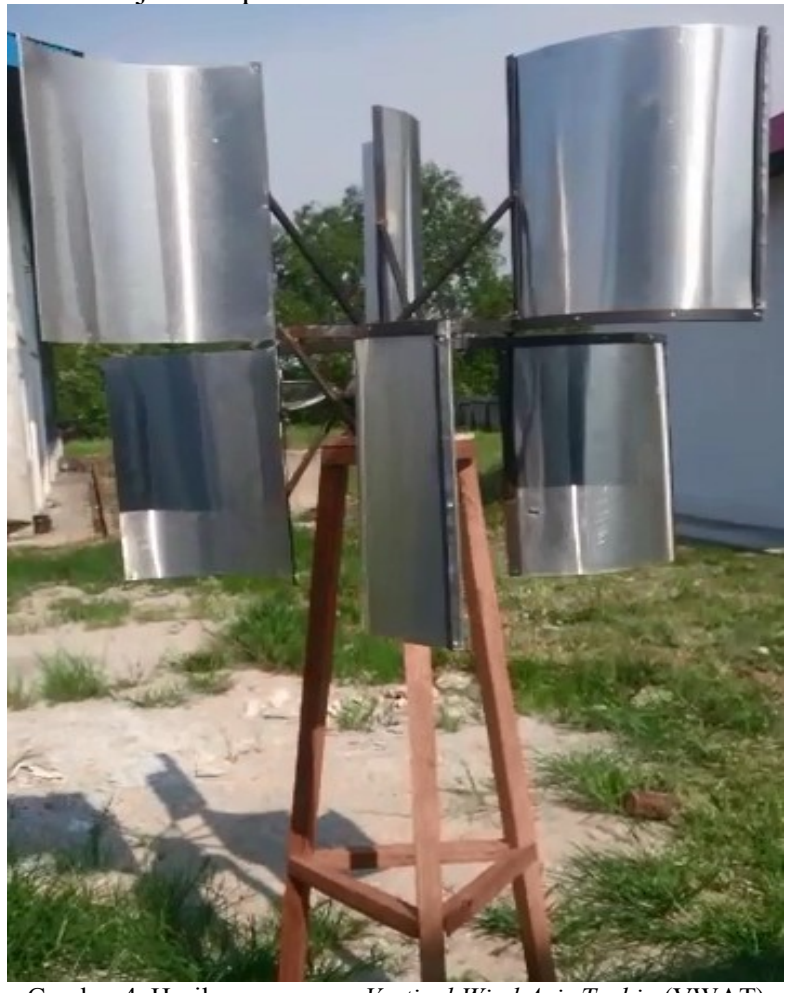

Gambar 4. Hasil perancangan Vertical Wind Axis Turbin (VWAT)
TABEL I.

HASIL PENGUKURAN TEGANGAN VERTICAL WIND AXIS TURBIN

(VWAT)

\begin{tabular}{|c|c|c|c|c|c|}
\hline \multirow{2}{*}{ No } & \multirow{2}{*}{ Waktu } & \multirow{2}{*}{$\begin{array}{c}\text { Kecepata } \\
\text { n Angin }\end{array}$} & \multicolumn{3}{|c|}{ Tegangan Generator Magnet } \\
\cline { 4 - 6 } & & & $\mathbf{L 1}-\mathbf{L 2}$ & $\mathbf{L 1}-\mathbf{L 3}$ & $\mathbf{L 2}-\mathbf{L 3}$ \\
\hline 1 & $09^{00}$ & 2,75 & 6,57 & 6,32 & 6,48 \\
\hline 2 & $10^{00}$ & 4,24 & 13,31 & 13,23 & 13,72 \\
\hline 3 & $10^{15}$ & 6,18 & 18,23 & 18,59 & 18,61 \\
\hline 4 & $11^{25}$ & 5,39 & 14,94 & 14,27 & 14,23 \\
\hline 5 & $16^{15}$ & 5,14 & 14,52 & 14,39 & 14,14 \\
\hline
\end{tabular}

Gambar 5 memperlihatkan tegangan keluaran generator magnet permanen dari jam $09{ }^{00}$ sampai $16{ }^{15}$ WIB. Kincir angin sumbu vertikal dua tingkat menggerakkan generator magnet permanen dengan kecepatan angin antara $2,75 \mathrm{~m} / \mathrm{s}$ sampai dengan $6,18 \mathrm{~m} / \mathrm{s}$.

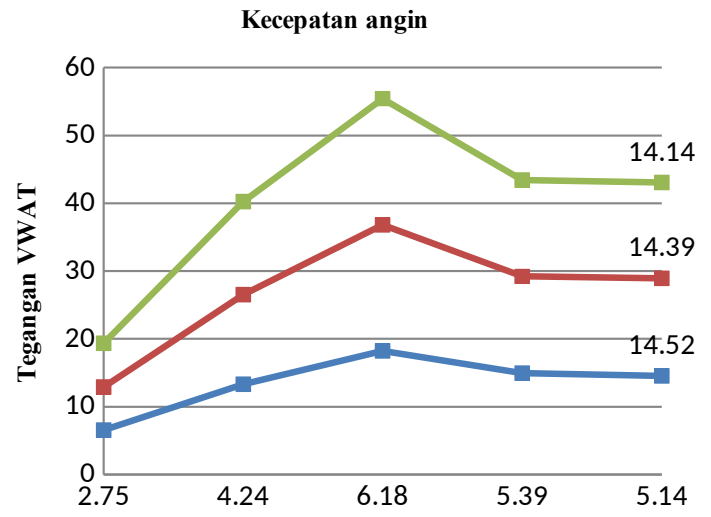

Gambar 4. Hubungan Kecepatan Angin Terhadap Tegangan Generator Magnet Permanen

Bentuk fisik dari rancang bangun sistem kontrol panel surya dua dimensi berbasis arduino diperlihatkan pada Gambar 5 .

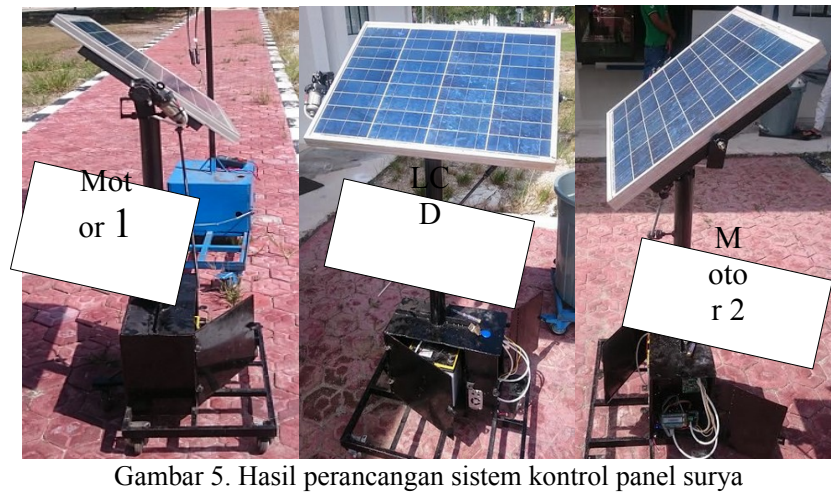

Pengujian dilaksanakan di ruangan terbuka. Pengambilan data dimulai pada jam $70^{30}$ WIB di Kampus Politeknik Negeri Bengkalis. Tegangan keluaran dari panel surya dikirim ke Arduino melalui sensor tegangan. Nilai tegangan di tampilkan di LCD 2. Data yang diperoleh dari pengujian berupa tegangan keluaran dari panel surya dan arus pengisian beterai charger pda waktu tertentu ditunjukkan pada Table II. 
TABEL II.

HASIL PENGUKURAN TEGANGAN PANEL SURYA

\begin{tabular}{|c|c|c|c|c|}
\hline No & Waktu & Manual 1 & Automatis & Manual 2 \\
\hline 1 & $07^{30}$ & 20,03 & 20,59 & 19,85 \\
\hline 2 & $08^{00}$ & 19,87 & 19,92 & 19,80 \\
\hline 3 & $09^{00}$ & 19,90 & 19,70 & 20,03 \\
\hline 4 & $10^{00}$ & 19,72 & 19,48 & 19,87 \\
\hline 5 & $11^{00}$ & 19,80 & 20,35 & 19,91 \\
\hline 6 & $12^{00}$ & 19,41 & 19,69 & 19,60 \\
\hline 7 & $13^{00}$ & 19,67 & 19,70 & 19,68 \\
\hline 8 & $14^{20}$ & 20,38 & 20,88 & 20,34 \\
\hline 9 & $15^{00}$ & 19,70 & 20,65 & 19,56 \\
\hline 10 & $15^{30}$ & 19,68 & 19,91 & 19,88 \\
\hline 11 & $16^{00}$ & 19,12 & 19,75 & 19,65 \\
\hline 12 & $16^{30}$ & 19,48 & 19,86 & 19,71 \\
\hline 13 & $17^{00}$ & 19,19 & 19,60 & 19,40 \\
\hline
\end{tabular}

Gambar 6 memperlihatkan tegangan keluaran panel surya dari jam $07^{30}$ sampai $17^{00}$ WIB. Panel surya yang memiliki kontrol sumbu $\mathrm{X}$ dan sumbu $\mathrm{Y}$ memiliki tegangan keluaran yang lebih tinggi dari panel surya yang dipasang secara manual.

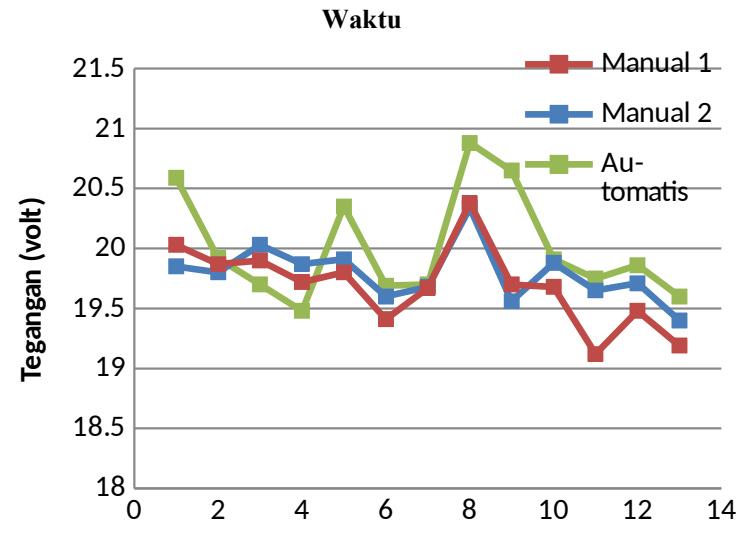

Gambar 6. Hubungan antara tegangan keluaran panel surya terhadap waktu

Bentuk fisik pembangkit listrik hybrid angin dan surya diperlihatkan pada Gambar 7.

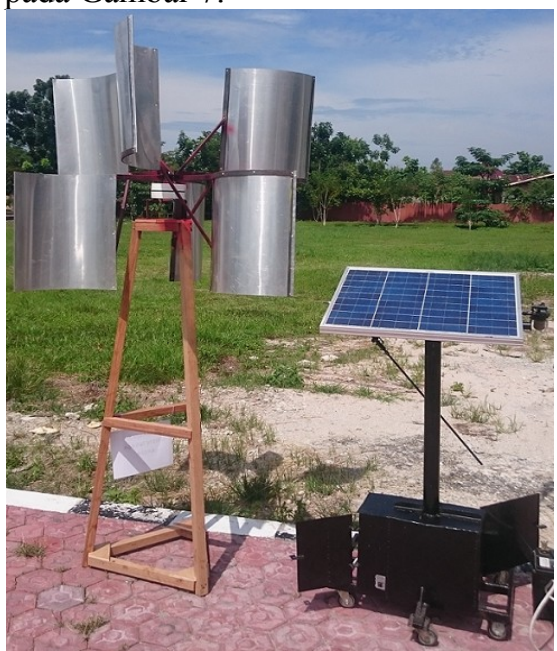

Gambar 7. Hasil pembangkit listrik hybrid angin dan surya

\section{KESIMPULAN}

Penelitian ini telah menghasilkan pembangkit listrik tenaga angin sumbu vertikal dua sumbu yang menggerakan generator listrik permanen. Kecepatan angin $2,75 \mathrm{~m} / \mathrm{s}$ telah dapat menghasilkan tegangan pada generator magnet permanen sebesar 6,48 volt AC. Tegangan yang dihasilkan oleh generator magnet listrik permanen pada kecepatan angin 6,18 sebesar 18,61 volt AC . Sistem kontrol untuk mengoptimalkan daya panel surya dengan pergerakan penampang panel surya pada sumbu X dan sumbu Y. Nilai tegangan yang dihasilkan oleh panel surya dapat ditampilkan melalui LCD. Daya yang dihasilkan dari panel surya sebesar 491 watt.

\section{UCAPAN TERIMA KASIH}

Penulis mengucapkan terimakasih pada Kementerian Riset Teknologi Dan Pendidikan Tinggi Republik Indonesia atas kesempatan untuk mendapatkan dana penelitian Hibah Bersaing. Penulis juga penulis mengucapkan terima kasih yang sebesar-besarnya kepada tim reviewer JNTETI atas masukan dan saran-sarannya

\section{REFERENSI}

[1] Fouzia B \& Said. M, "Dynamic Response of a Stand Alone DC Side Wind Energy Conversion System with Battery Energy Storage," Science Direct Energy Procedia, Vol. 50, hal. 97-104, 2014

[2] A.A.Safe, Saad Kashem, M.Moniruzzman, dan M.T Islam, "Design, fabrication and analysis of twisted blade vertical axis wind turbine(VAWT) and a simple alternator for VAWT," IEEE Strategic Technology (IFOST), Vol. 9, hal. 304-308, 2014

[4] Amar M \& Imam A, "Rancang Bangun Sistem Penjejak Matahari 2 Sumbu Berbasisi Kontrol Adaptive Neuro-Fuzzy Inference System (ANFIS), “ Jurnal Sains dan Seni Pomits, Vol . 1, hal. 1-6, 2012

[5] Joko P, Muchlas, dan Tole S, "Sistem Kendali Penjejak Sinar Matahari Dua Lintasan Kebebasan Berbasis Mikrokontroler AT89C51. Telkomnika, Vol. 6, hal. 191-198, 2008

[6] Mairizwan \& Hendro, "Perancangan dan Pembuatan Prototype Sistem Tracker Sel Surya untuk Mengikuti Arah Gerak Matahari Berbasis Mikrokontroler Atmega328, “ Prosiding Simposium Nasional Inovasi dan Pembelajaran Sains 2015 (SNIPS 2015), hal. 101-104, 2015

[7] Wiratama. IK, "Pengaruh variasi jumlah blade turbin angin terhadap output daya listrik," Dinamika Teknik Mesin, vol 4, hal. 25-29, 2014

[8] Yudhy. W.J.K, Noer S, Agus T, dan Dikpride D, "Rancang Bangun Penggerak Otomatis Panel Surya Menggunakan Sensor Photodioda Berbasis Mikrokontroler Atmega 16," Electrician - Jurnal Rekayasa dan Teknologi Elektro, Vol. 9, hal. 11-20, 2015

[9] Noer S \& Osea Z, "Sistem Pelacak Otomatis Energi Surya Berbasis Mikrokontroler ATMega8535," Seminar Nasional dan Expo Teknik Elektro, hal. 52-55, 2015

[10] Bala K \& Rajesh S, "MMPT Controller Base Solar Tracking System," IOSR Jurnal of Mechanical and Civil Enggineering (IOSR-JMCE)., hal. 78-83, 2014

[11] Baipai P \& Kumar S, \&Design, Development and Performance Test of An Automatic Two-Axis Solar Tracker System," Annual IEEE India Conference (INDICON). Hal. 1-6, 2011 